\title{
The multiple functions of criollo, gaucho and indigenous symbols in la historieta Patoruzú, 1936-50: The conflicts of Peronism, nationalism, and migration.
}

This article considers the comic book, Patoruzú in light of the cultural expressions of Argentine criollismo between the 1930s and 50s. It begins by examining the political and class conflicts that informed the meanings of criollo symbols, and how Dante Quinterno's creation interacts with them. Perón's political organisation, for example, constantly resorted to discourses and images of a gaucho and rural nature in order to propagate the ideals of nationalist corporatism. From one perspective, the drawings, storylines and characters of Patoruzú articulate the arguments set forth by Perón in his battles with neo-colonial and oligarchic forces. However, as Cohen (1995) and Hall (1980) argue, mass-media products and popular national symbols are dialogic; they enter into a dialogue with different competing discourses. Thus the comic book is also analysed in respect of the different and conflictive uses and potential interpretations of criollo symbols. One such conflict, it is proposed, resides in the understudied effect of modernization and urbanisation on the rural criollo migrants, who moved to the provinces of Buenos Aires in large numbers in the 1930s. The comic book, therefore, is not simply understood as an expression of Peronist ideals, but as a footprint of the complex political and identity conflicts of the period.

Keywords: Criollismo, Peronismo, Patoruzú, Migration, Class and Identity Conflicts

Dante Raúl Quinterno's comic-strip character Patoruzú first appeared in the newspaper La Crítica in 1928. Two years later the author transferred his talents to the newspaper La Razón, where he continued to develop the features of his most famous creation. Due to the demands of the comic's large fan base, Quinterno began to publish a bi-monthly magazine in 1936, named Patoruzú, which would soon become a weekly feature. It would go on to be one of the most popular comics for the next three decades, selling more than 300,000 copies a week (Fiorani 2015, 289) and surpassing its rivals, Rico Tipo and Intervalo. ${ }^{1}$ Its success and cultural importance have led a handful of critics to analyse the comic's protagonist. Most of them (Quiroga Micheo 1994; Fernando Ariel García 2014; Malatesta 1997) focus on the characteristics of Patoruzú: his moral fibre, and his superhero antecedents. Others, such as José Gobello (2004), examine the guachesque language employed by the author and place the comic within the tradition of costumbrista works. Very few, however, have analysed the meanings of the comic and its main characters within the political, cultural and social contexts in which it was published. Although it is not the principal focus of their work, Steimburg (1982, 161-64) and Matamoro 
$(1980,158)$ identify nationalist ideologies in the comic's treatment of criollo identity. Lipzic $(1982,13-5)$ goes further still by accusing Quinterno of regurgitating xenophobic and anti-Semitic fervour under the guise of nationalism in the comic strip. While Quiroga Micheo $(1994,39)$, Fiorini $(2015,138)$ and Malatesta $(1997,46)$ contend that the comic strip and its character express a more innocent type of patriotism. ${ }^{2}$

These latter articles view the criollo imagery, themes and narratives employed in Patoruzú as an unproblematic and monolithic symbol of national identity. What they fail to take into account is the multiple and contradictory forces that have shaped and given meaning to the criollismo phenomenon that dominated much of the cultural production from the 1910s to the 1950s in Argentina. This article, in contrast, examines the editions of Patoruzú produced between the late 30 s and early 50 s from the perspective of the dynamic class and cultural conflicts that informed the discourses of Argentine nationalism, and more specifically popular and literary forms of criollismo. As Stuart Hall (1980) argues in his seminal essay "Encoding/decoding", mass-media texts are relatively open and prone to being interpreted in different ways by different people, from different echelons of society. Similarly McAllister (2001, 3-4) proposes that the comic book, with its idiosyncratic combination of pictures and words, is a 'potentially polysemic text, encouraging multiple interpretations'. The same can be said of the symbols employed to represent national identities, such as the criollo or gaucho. ${ }^{3}$ According to Anthony Cohen (1995) both linguistic and pictorial symbols of national identity are dialogic; their meanings are defined by a constant interaction with different discourses of class, as well as cultural and gender groups.

Employing these arguments, this article investigates the ways in which the images and narratives in Patoruzú necessarily entered into a dialogue with an already existing archive of criollo images and the political, cultural and class conflicts that circulated within them. In the first half it examines the many parallels between the comic and the Peronist party's adoption and adaption of criollo imagery in line with the contemporary discourses of nacionalismo popular. However, as we shall see, Peronism was also subject to internal class conflict or at the very least class difference, which surfaces in Dante Quinterno's depiction of criollo identity. On another level, due to the historical uses of criollismo, the images and narratives in Patoruzú can also be interpreted though the ideologies of opposing political groups, such as the regional elites, whose employment of criollo symbolism to justify their position of power long predated that of Peronism. Finally, in the latter half, the article turns its attention to an aspect that, while intrinsically linked to Perón's political success and promotion of criollo imagery, has been totally ignored by other critics of literary and popular criollismo: the mass internal migration from rural areas to the urban centres that took place in Argentina between the 1920s and 50s. Here it is 
argued that the comic book, along with other examples of popular uses of criollo culture, acted as one of the many cultural and political bridges between Peronism and this new and important support base. However, at the same time, certain narratives and images in Patoruzú simultaneously mirror the ethnic and cultural tensions and the effects of displacement brought about by this demographic shift, which reveal the deep contradictions that lay at the heart of Perón's idolisation of rural Argentine society. As such, the purpose of this article is not only to examine one of the most successful comics in the cultural history of Argentina and its links with the political conflicts of the time. It also aims to shed new light on the cultural production of criollismo by focusing on the role played by the rural migrant in its propagation and the creation of its multiple meanings.

As Oscar Chamosa (2010, $196 \mathrm{ft} 3)$ observes, the term criollo contains its own ambiguity: '[T]he term criollo did not distinguish individuals of older European ancestry, such as the land-owning elite, from acculturated individuals of mixed race or mostly indigenous backgrounds'. This lack of clarity has led to two cultural and ethnic meanings of the term. The first being rural traditions and peoples which, despite sharing clear links with both indigenous and Spanish colonial practices, have been represented predominately in terms of their Hispanic ancestry, due to the Argentine elite's promotion of Argentina's 'European' cultural and racial heritage. The second is the ethnographic and folklorist concept of the term: a mixture of indigenous and Spanish cultural and ethnic traits, which Chamosa designates as rural or mestizo criollo. This concept, it should be explained, is heavily influenced by the ideological objectives of the trans-Latin American political and literary movements of indigenismo and mestizaje of the $30 \mathrm{~s}$ and $40 \mathrm{~s}$, and was employed in order 'accentuate the Latin-American identity of Argentina' (Adamovsky 2015, 41) in opposition to the cosmopolitan and/or westernised practices of the urban centres. In this article, I will use the expression criollo to refer to the Hispanic model, which was mainly promoted within criollista literature, and produced principally by urban writers and artists. In the latter half of the article, I use the term mestizo criollo specifically in reference to rural groups (and representations of them) that consciously advocated indigenous roots in political and/or cultural terms.

Criollo identity was of course informed by earlier conflicts and discourses that are older than the country Argentina. By the early 1900s it was already a symbol of national/local identity in opposition to the imposition of foreign ideas and goods. As Penna and Ras $(2002,85)$ observe, the antagonism between the westernised and cosmopolitan society of the littoral zone and the traditional societies was then further exacerbated during the Civil War. However at the turn of the nineteenth century the conflict became more complex due to the policy of immigration. At least 6 million peoples immigrated to Argentina between the 1880s-1900s. Although the latest records suggest that only 3 million actually settled permanently in the country (Tur 
Donatti 2008,114$)$, this wave of mainly European immigrants drastically changed the demography of both the urban and rural zones. The demographical make-up of the country was modified again between the 1920 s and 50 s by, this time, internal migration. During these decades the collapse of the agro-exporting economic sector and a boom in industrialisation meant that many campesiños (rural peoples) were drawn to the cities. ${ }^{4}$ As Cullen $(2009,29)$ points out, these migrants became industrial workers and, in the process, brought about an important transformation in the composition of the urban working class. ${ }^{5}$ These two types of immigration as well as the modernization of agricultural practices brought an end to, or at least radically changed traditional rural customs and identities in Argentina.

In general terms, it has been argued that these changes provoked nostalgia for the past that the literature and popular culture of the period expressed through the figure of the gaucho and criollo. ${ }^{6}$ Writers, like Ricardo Güiraldes, Leopoldo Marechal, Manuel Galvez, Ricardo Rojas and, above all, Leopoldo Lugones in his study of gaucho culture, El payador (1916), promoted the reconstruction of Argentine national identity which vindicated 'el tronco fudamental' (the fundamental trunk) by which Penna and Ras $(2003,151)$ mean indigenous and colonial Spanish cultural values and traditions. Simultaneously, criollo and gaucho customs became an important feature in comic books, such as Tigre de los Llanos (1929) and La estancia del Ombú (1939) and El audaz (1939), which, according to Ana Merino $(2015,156)$, 'develop the deep folkloric idea of the gaucho'.

This explosion of nostalgic representations of folk traditions reflects, on the one hand, aspects of Western Romanticism's idealised narratives of rural life in the face of industrial change. On the other hand, it also expresses an interlacing of nationalist discourses and what Karush (2010) calls the logic of market. While, as we have seen, the criollo was already a symbol of anti-foreign sentiment, during the 30 s and the 50 s this discourse was rearticulated in the rivalry between local productions of popular culture and external imports such as Donald Duck: 'la etapa se hizo resaltar no solo la importancia de una producción local enfrentada a una industria internacional, sino tambien la necesidad de que estas producciones revelen la "idiosincrasia nacional"' (Vásquez 2010, 31). At the same time, growing class tensions were being channelled through popular criollo and folkloric productions. The mass culture of the 1930s constantly associated the criollo and their traditions with the rural and urban poor and their battle against the oligarchy and their foreign allies (Karush 2010, 29). This narrative was soon amalgamated into Perón's own nationalist rhetoric and political aims (Chamosa 2010a). Thus, the criollo became a symbol in which discourses of an 'authentic' Argentine identity, the logic of the market, and political/class struggle intersected (Chamosa 2010a, 121). 
The political and class conflicts of this period are clearly articulated within the delineation of the characters and the story of Patoruzú. The comic strip's main character is the eponymous hero Patoruzú. He is a caudillo of the Tehuelche tribe, who has come to Buenos Aires, with a bottomless supply of gold nuggets in order to learn about western and urban civilisation. It comes, of course, as no surprise that the representation of the Tehuelche culture is anything but accurate or that it has no pretensions to be 'authentic' or factual. In fact, Patoruzú is symbolic of a romanticised gaucho and criollo identity, so widely disseminated in the period. His ability to sing payadas (folk songs), to dance rancheras (folk dance), and las boleadoras (hunting equipment) that he uses, as well as his gauchesque language (Gobello 2004) identifies him with the Argentine countryside and the figure of the gaucho, which, of course, thanks to Martín Fierro (1872), was already an important symbol of idealised criollo identity. The second most important character is Isodoro Cañones, Patoruzú's padriño (godfather). He is an urbane and 'sophisticated' porteño (resident of Buenos Aires), who 'educates' the 'indian', but who is really only interested in tricking him out of his bags of gold and inheriting his riches. The other important character his Upa, Patoruzú's younger brother, who is also in the city to learn to be 'civilised', although, in reality, he is corrupted by the padriño.

In the comic, then, we have two characters that represent polarised cultural and moral values. Patoruzú is the honest, extremely gullible, but always moral gaucho/criollo/indigenous character. He is the hero who saves the day when quite often the padriño's Machiavellian schemes have put everyone at risk. These romanticised aspects of Patoruzú's identity are further emphasised by his telluric relationship with the natural world, which is the source of his super strength, and the way in which Quinterno's team depict the character. Patoruzu's long face, large nose (a characteristic of his indigeneity within the narratives of the comic book) and the exaggerated dimensions of his oval shaped eyes, which are often employed to communicate a sense of childish, energetic curiosity, as well as his broad smile all work together to convey attitudes of innocence, generosity and naivety. On the other hand, the wedge shaped eyes of the padriño, his thin mouth, and constant frown are symbolic of the greed and egotism of the character, which we are clearly meant to relate with his cosmopolitan and urban identity. He wears a frac, for example, and speaks what Quiroga Micheo $(1994,39-40)$ calls 'un castellano deformado, gringo o cocoliche', which is also heavily influenced by French idioms. He is also addicted to all the vices of the capital: gambling, drinking, pretentious consumerism and women. As Matamoro observes $(1980,158)$, these characteristics clearly associate him with the traditional oligarchic class of the period (albeit one of those who have fallen on harder times), or to be more exact with the spoilt, selfish and profligate niño bien of Argentine cinema of the period. 
It is also interesting to note that in the editions examined in this article almost all Patoruzú's enemies are foreign. El Cacho is Spanish, the Gitanos are foreign, there is a Russian villain, Ivan el Terrible, El Joe is an Italian mobster, El Inglés is a corrupt jockey who attempts to rob Patoruzú's horse. El Mandiga, Patoruzú's archenemy is foreign and sophisticated, and the language of the professor who tries to swindle Patoruzú out of his territory in Patagonia is clearly of Eastern European origin. In short, his enemies are almost always associated with European or cosmopolitan traits and, therefore, mark a direct link to the corrupt cultural and immoral values of the porteño Isodoro.

As Matamoro $(1980,158)$ observes, the delineation of Patoruzú and the porteño Isidoro is clearly informed by the well-known Roussean binary of the 'natural' primitive and the degradation of civilised society. However the characters and storylines are evidently overlaid with references to the class conflict that became the bedrock of Peronism from 1943 onwards. One of the bitterest enemies of Peronism was the Argentine oligarchy, who made their money through the agro-exportations. They were also the promoters of economic liberalisation and cultural westernisation in Argentina. The general propaganda of Peronism and other parties, such as the Partido Laborista, through which Perón rose to power, was that the wealthy few were selling off Argentine patrimony and resources (natural and human) to the neocolonial force of the United States for their own gain. Isodoro's cosmopolitan characteristics, his immoral behaviour, and his constant attempts to swindle Patoruzú out of his gold are clearly meant to be read as a criticism of the oligarchy's 'treachery'.7

The comic expresses these conflicts of political and class identity in almost all Patoruzú's adventures. In general, the narrative of each storyline spans more or less 12 editions of the comic (3 months worth of weekly editions). These narratives almost always revolve around a story of a character who has been defrauded out of property or land, by a crook or set of crooks, who, as I have said, are almost always foreign. In all cases the denouement of the plot depends on the revealing of false documents of ownership and the discovery of the authentic documents. Perhaps the most interesting version of this storyline is the one that features in the December, January and February editions between 1944-5. It concerns Patoruzú's tribal territory and genealogy in Patagonia. In n. 380 a professor of ancient languages manages to convince Patoruzú with a false parchment written in an indigenous dialect that his father had tricked the Queranventes (another indigenous group) out of their territory by inebriating them with 'chicha' (beer made from corn) (25 December, 1944, 6). The gullible Patoruzú falls for the trick and signs over the land to the Queranventes, who are in cahoots with the professor, which results in the evacuation and exile of his family members. Later, as always, the professor's document is proved to be false by the discovery of the real 'testament' which confirms the Tehuelches' right to the 
territory. It is then revealed that the professor (an urbane foreigner as always) had attempted to swindle Patoruzú out of his ancestral land.

This storyline and others in Patoruzú clearly articulate the binary of good and evil that was depicted in melodramatic cinema of the time, which became the steadfast ethos of Peronism (Karush 2010, 23). According to Fernández Latour de Botas and Ruiz de Barrantes (1990), such discursive battles were constantly played out in different mediums like opposite claims in a court case about the ownership of Argentina. The rivalry between the classes and political factions also spilled over into skirmishes about what Argentina was or should be. The following differences of opinion on the relevance of so-called folkloric and rural culture to national identity clearly demonstrate the schism between the two camps. For example, Augusto Rául Cortázar argues, in his aptly named book El folklor y el concepto de nacionalidad $(1939,10)$, that Argentine rural traditions are the cornerstone of national identity. In contrast, Juan Alfonzo Carrizo (quoted in Fernández Latour de Botas and Ruiz de Barrantes [1990, 88]) accuses folklore of representing the Spanish empire and provincialism. For him the nation should be based strictly on the liberal concepts of the French Revolution.

Interestingly this phenomenon of two constructs of one identity and one reality permeates the comic Patoruzú in other ways. In all the storylines two versions of one actuality exist at the same. In the February and March editions of 1942, which feature the two criminals Mr Danger and Joe el Mafioso, the narrative involves two versions of one horse. Here Isidoro has robbed Patoruzú's horse in order to sell it to Mr Danger in order to make money on the races. The corrupt padriño must persuade Patoruzú that the horse running for Mr Danger, which is really Patoruzú's, is another horse entirely. Thus in the drama of this episode there are two horses, one which is based on its true identity, and on which is based on a false one.

The plots of the different episodes in Patoruzú clearly reflect, therefore, the litigation between two versions of one country. It is also interesting that almost all the cases are solved by the discovery of a document with which it is possible to associate the premier document of national identity: the constitution. The allegorical message implied in these storylines of Patoruzú seems to be relatively unambiguous. It is the criollista Argentina which is represented as the legitimate one and, therefore, given that such images became associated with Perón's own politics, the comic strip, on the face of it, at least, expresses a certain political position.

However, Perón's promotion of criollo identity 'had several pitfalls and contradictions' (Chamosa 2010a, 123). Prieto's article $(1988,13)$ shows that certain elements of the urban oligarchic establishment were already using criollo symbols as a means of affirming their legitimacy, especially in the face of the challenges of 
foreign discourses, such as anarchism and socialism. According to Elena de Lorenzo Álvarez (2015), Martiniano Leguizamón's Calandria (1896) is an example of this employment of elitist criollismo. Moreover, Chamosa $(2010,3)$ notes that the folkloric movement was promoted, in part, by regional elites from the interior 'as a way of protecting their economic and political interests'. ${ }^{8}$ Patoruzú, given that his enemies sometimes are loosely drawn from Eastern European identities and the fact that he is a rural cacique who protects the poor and 'national' rural values, could also be interpreted in this way. Either way the comic book reflects the way in which the Peronist promotion of criollismo coincided uncomfortably with images being employed by those deemed to be the party's and the people's enemies.

On another level, Patoruzú also displays the cracks between the different classes that constituted the Peronist party. Karush $(2010,24)$ observes that socialist or Marxist class discourse was not a principal ingredient of Perón's political rhetoric. Rather he sought to realise 'class reconciliation and social harmony' $(2010,24)$ under the guise of national corporatism. However this does not mean that Peronism was free of class antagonism. Rafeal Cullen $(2009,43)$ points out that Perón's party as well its socialist arm 'from its origins was run by professionals of the middle classes'. Indeed, the idealistic images of criollo identity in the literature and popular culture and politics of the time can be seen as the product of a growing conflict between a burgeoning middleclass and the oligarchy. Penna and Ras $(2003,151)$ certainly affiliate the romanticisation of criollista and gaucho culture produced by middle-class writers with the clamours for economic nationalisation and workers' rights that the Peronist party plugged into on its road to success.

This trend also reflects the dynamics of indigenista and neo-indigenista literature of Peru in the 40s and 50s. According to Cornejo Polar $(1997,60)$, in Peru this literary movement was made out of mainly middle-class authors who employed narratives about the mistreatment of the indigenous peoples to attack the oligarchic class. In the Argentine context David Viñas (1982) argues that urbanised middleclass writers and artists, often with very little knowledge or contact with the interior, also appropriated images of rural life, indigenous, gaucho, and criollo identities in order to promote their own ideology and to denigrate the opposition. Patoruzú's naivety, his 'natural' goodness, his relationship with the earth display many of the stereotypical aspects designated to indigenous peoples by non-indigenous writers. ${ }^{9}$ It is also interesting to note here that Quinterno himself, according to Fernando Ariel García (2014), had political affiliations with both socialism and later on with Peronism. In this respect, the battle between the 'authentic' criollo Patoruzú, and the duplicity of the porteño Isodoro and the various foreign enemies should be understood, in part, as an expression of the growing conflict between the middleclass and the oligarchy, which reflects the contradictions and class chasms within Perón's political movement and its employment of criollo imagery. 
The thematic claims made throughout Patoruzú which promote the criollo figure as the 'authentic' representation of Argentine identity reveal other links with the contradictions expressed in Perón's nacionalismo popular. In order to reveal these we must once again place the comic in the context of literary criollismo, and literature in general. Matthew Gelbart (2007) observes that the concept of high literature paradoxically invented the binary between rustic culture and refined artifice, but, at the same time, was dependent on a combination of the two. In the movement of Romanticism idealised folk elements were employed as an authentic ingredient out of which the sophisticated artist could produce a distinguished example of national art or literature: national masterpieces, in other words. Such observations are clearly applicable to the some examples of criollista literature: the poem Martin Fierro or the novel Don Segundo Sombra (1926), for example. Jorge B. Rivera's (1991, IV) claims that certain comic books, such as El audaz (1939) by Enrique Rapela and El Huinca (1957), also exhibit 'la profunda sabiduría del dibujante en material de paisajes, prendas y costumbres [...] rurales', clearly places these works within the same rubric. Borges (1987), of course, famously highlighted the falsity of any kind of literary and/or representational claim to authenticity. However the case of Patoruzú is different. It certainly seeks to paint criollo identity as the 'authentic' expression of the Argentine nation. Yet it quite clearly has no pretensions to be considered a faithful manifestation of that cultural tradition. In fact it revels, perhaps even self-consciously, in its comic artifice. The protagonist's appealing and humorous physical characteristics constructed via the use of oval shapes and broad dynamic brushstrokes, his stereotypical garments (head feather, sandals, and boleaderas) as well the other aforementioned psychological ones of comic naivety and innate goodness, could be construed as a light parody of the representations of rural customs and peoples so widely disseminated from the 1920 s onwards.

The paradoxical stance in Patoruzú displays some similarities with the contradictions of the logic of the market that Karush (2010) identifies in commercial melodrama of the 1930s. Karush $(2010,32)$ proposes that producers of cinema and radio shows soon began to attempt to attract wealthier consumers away from foreign imports by softening the links between the representation of a principally criollo, plebeian class and the discourse of national 'authenticity'. This re-packaging of 'Argentinidad' produced 'an ambivalent mass-culture' which 'contained deep and persuasive contradictions' (Karush 2010, 32). In cinema and radio the inconsistencies revolved around the discrepancy between the representation of the poor as a uniquely 'authentic' illustration of Argentine identity and the promotion of an individualistic upward mobility. The humorous traits in Patoruzú, described above, are without doubt partially the product of a commercial attempt to soften the political edges of criollo images and narratives in order to attract a wide as possible range of readers from different walks of life. 
The strategy to dovetail the representation of criollo identity to the demands of the market is related to another, arguably deeper-seated, incongruity that runs throughout the comic book (and through other commercial expressions of criollismo). This one lies in the complicated relationship between the two principal concepts of popular culture in Latin America in the twentieth century: that it means, on the one hand, 'of the people, belonging to their cultural practices' and, on the other, the modern culture industry (Poblete 2016, 13). In line with the arguments of academic folklorists of the time, Patoruzú delineates the criollo as the 'authentic' identity and cultural practice of the Argentine people. Nevertheless it belongs to the realm of commercialised popular culture produced by the modern entertainment industry, which is generally seen in opposition both to 'authentic' folk/criollo traditions, and national expressions of high art and literature. ${ }^{10}$

Karush $(2010,44)$ convincingly argues that the ambivalence of melodramatic cinema and Tango songs fed into Perón's political discourse. We can also see a similar symbiotic relationship between the contradictions of commercialised criollismo and the popular political uses of criollo symbols in the 40s and 50s. During the rise and zenith of Peronism, the urban and rural poor, who had had no say in politics and or influence in the nature of national symbols, entered the political and media spheres through the discourses of nacionalismo popular (Penna and Ras 2003, 255). This is partly because Peronism, and before its existence, the Partido Laborista strategically sort the support of the poor rural criollo as well as the humble European migrants in the cities. ${ }^{11}$ According to Adamovsky $(2015,39)$, for Perón the aim was to channel these different groups into a corporate body in which national and/or class identity would become the dominant narratives. Certainly Patoruzú can be interpreted as functioning in this way. It is a comic book, after all, about a Tehuelche from Patagonia who settles in Buenos Aires.

Unsurprisingly, Peronist and pre-Peronist popular nationalist propaganda share similar contradictions with Patoruzú in their representation of rural traditions and identities. As Stiemburg (1982, 166-7) observes, the comic's constant reference to Patoruzú's Tehuelche, criollo and gaucho cultural practices are riddled with inconsistencies. The major one being that the indigenous peoples occupied a different social and geographical space and practiced quite different cultural traditions to those of the gauchos and criollos. Secondly, the gauchos were partly responsible for the near extermination of different indigenous groups in the Conquista del desierto (the conquest of the desert) campaign. Such a contradictory alchemy was also quite typical in Peronist propaganda. Adamovsky $(2015,54-7)$ observes that criollo, gaucho and indigenous images were interchangeable in the political magazines of Peronism, such as La Laborista. What was important was not historical or ethnic accuracy, but that these images were amalgamated into a narrative of 'authentic' working-class and nationalist identities $(35-7,56)$. 
They are, interestingly, several crossovers between the comic and the images of propaganda used by Perón's party, such as the famous posters featuring Juan Pablo. In general these posters not only associate criollo identity with the working class, they also imply the importance of the agricultural production of the interior and of the rural criollo in achieving the goal of industrial modernization and economic independence. Many of the Patoruzadas, the one page comic quicks that feature the comic hero, mirror the general message of these Peronist posters. Patoruzú is consistently depicted as saving or at times replacing the energy needed to run the city's modern infrastructure. In the Patoruzada of $n$. 283, for example, Patoruzú is depicted as pushing the cars so the porteños can get to work because they have run out of 'nafta' (fuel) $\left(15^{\text {th }}\right.$ February, 1943, 20). In others Quinterno delineates the hero pulling trams or replacing electricity. In these one-page comic frames, the significance of the imagery is emphatically clear: it is the rural migrant who is underpinning the industrial development. The messages and images of many of the Patoruzadas and the political propaganda of the time often overlap in strikingly clear terms.

In this respect, the incongruous combination of criollo, gaucho and indigenous symbols in Patoruzú are part and parcel of a process in which new working-class, national identities were being constructed by the Peronist and other parties, with the aim of subsuming criollo and European migrants into these discourses. In other words, they functioned as symbols that circulated within the public and private spheres in verbal and non-verbal forms. As John Armstrong (1982) argues, symbols mark identity boundaries, such as national ones. One way in which they do this is by associating contemporary narratives of national identity with an idealised past (Smith 2003; Hobsbawn 1992), which bestows the nation with a spiritual and mythical origin. Patoruzú and other examples of nacionalismo popular combine the symbols of the criollo, gaucho and indigenous identity in order to imply a relationship with a past before the existence of the nation. Through numerous depictions of Patoruzú (his bonds with his ancestors and his tribal territory), the comic paints a quasi-mythical and foundational relationship between the land and the nation, of which the episode that concerns the protagonist's territory, discussed above, is the most obvious example.

Anthony Cohen $(1995,20)$ proposes that such symbols become more important when the boundaries between social and geographical groups become undermined. In the early half of the twentieth century, due to external and internal migration and industrial development, this is exactly what was happening in Argentina. Different groups from European and other countries and from the interior of Argentina were converging on the cities and were having their lives radically changed by the policies of industrialisation. In this kind of context symbols of cohesion and group identities are in constant need of reproduction and embellishment (21) which helps explain the 
sheer volume of gaucho and criollo imagery and narratives in political discourses, literature, film, comics, and even street parades and re-enactments. They are also typically sutured onto other abstract values: such as 'virility' and 'authenticity', in opposition to 'femininity' and 'inauthenticity' (21). These types of values, as we have seen, are an important ingredient in the narrative of Patoruzú. The hero of the comic book clearly represents masculinity and legitimacy in the criollo guise, while Isodoro embodies the femininity, falseness and pretentiousness of Anglo-French cosmopolitanism. Thus it is possible to view the editions published from the mid $40 \mathrm{~s}$ as an ideological bridge between the rural migrants and Peronist corporate nationalism, whose political success depended on the support of this group (Chamosa 2010a, 134; Milanesio 2010, 53), as well as rural communities who had remained in the interior (Adamovsky 2015, 156).

However, this model represents the migrants, including those from foreign countries, as passive receptors of Peronist propagation of criollo imagery. The function of such symbols in fact goes beyond such a simple binary. Cohen (1995) proposes that in modern and multicultural nations symbols are not static or stable. Rather, 'they provide people with the means to make meaning. In doing so, they also provide them with the means to express the particular meanings the community has for them' $(1995,15)$. This observation leads us to consider the possible meanings of criollismo from the perspective of the rural and foreign migrants. As far as the latter are concerned, Prieto (1988) implies that they were far from inert consumers. Although his book centres principally on the literary constructions of criollismo published before the 1930s, Prieto's observation that the rural migrants themselves were vitally important in disseminating their cultural practices in the cities is of relevance here since it shows the criollo migrants as active agents of cultural production (12). Adamovsky (2015), referring specifically to the migrants of Perón's era, is even more explicit about the cultural and semantic agency of this group, especially those who saw themselves as mestizo criollos. He proposes that certain uses of criollo imagery were seen as a legitimisation of a mestizo ethnicity and culture that challenged the racial prejudices and ideologies expressed within 'el mito' (the myth) of the Argentine population as 'plenamente blanco y europeo' (fully white and European) (Tur Donatti 2008, 114).

It is of course difficult to accurately gauge how many of the rural population and internal migrants were politically and/or culturally aware of their mestizo cultural or ethnic roots, mainly due to renewed and successive discursive strategies to erase this identity from the national imagery after the 1950s (Adamovsky 2015, 58). Certainly many supporters of Perón received the extremely racist designation of 'cabecitas negras' (little blackheads) because of their indigenous features (Penna and Ras 2003, 257; Milanesio 2010, 53). The latest genetic tests performed on the Argentine populace suggests that many more were (and are) mestizo than official 
state figures, to this date, have been prepared to admit. Today $56 \%$ of Argentines have partial or complete indigenous genetic ancestry (Tur Donatti 2008, 115). Given that indigenous and mestizo cultural societies reside mainly in the interior of the country, it seems fairly logical to conclude that a good number of these internal migrants would, in different degrees, have had their identities formed within rural and mestizo cultural traditions and belief systems. Indeed Penna and Ras (2003, 156) argue the European migrants, who settled in the pampas areas and further afield in the 1890s, were at least partially subsumed into the social fabric of the residing groups, and adopted their cultural traditions and concepts of identity. ${ }^{12}$

Furthermore, Adamovsky (2015) suggests that many of the recently urbanised, rural migrants were extremely aware of their cultural and ethnic differences. Many came into contact with the growing socio-political movement known as indigenismo, in which the indigenous heritages of certain Latin American countries were being reassessed. Thus it is quite possible that the migrant mestizo criollos would have processed the images that associate Patoruzú with nature and certain rural traditions, such as the payadas and rancheras, via these discourses of identity. The comic book can also be seen, therefore, as a mass-media product that interacts with the type of identity conflicts that Schelling (2000) and Larraín (1997) define as an important narrative in twentieth-century Latin American modernity and modern cultural productions; or modernism, in other words. This particular kind of clash between local traditions and global culture has been all but ignored in the Argentine context, due to the dominant discourses mentioned above which painted and continue to paint the populace of Argentina as purely 'white' and 'European'. Yet, as Adamovsky argues (2015), the employment of criollo and gaucho imagery opened up a space through which a conflict between local, established Catholic and indigenous customs (i.e., mestizo criollo identity) and the imported ideas of western modernity, culture and capitalism resurfaced during Perón's rise to power and reign.

However, as García Canclini observes (1990), such cultural conflicts today or in the past are not based on a fair and even distribution of power. In Argentina not even the Peronist party, despite its continual use of mestizo criollo imagery, sanctioned a mestizo vision of Argentina (Adamovsky 2015, 39). As we have seen, one of the objectives of criollismo was to impose the discourse of 'crisol de razas' (crucible of races) in which no internal differences were allowed, and in which the Hispanic heritage was promoted above others. On the other hand, we have seen that the majority of criollo images were also invested with class concerns and desires and/or the logic of the market, which tended to result in the production of a romanticised and generalised version of rural culture, envisaged principally through the western paradigms of the 'other': innocent morality and/or authenticity. As such, Patoruzú and other popular examples of criollismo are also a reflection of the transformative effects of modernity on the rural migrants, and the discursive relations of power in 
which they were now caught up. Not only were their lifestyles being radically changed by the processes of modernity (urbanisation, politicization and industrialisation), they were confronted on a daily basis with reconstructions of their own cultural identity that were heavily influenced by extraneous political and class objectives and market forces.

The very genre of the comic book is also intricately related to these issues. Taking her lead from Ian Gordon's study of North-American comics from 1890-1945, Ana Merino $(2003,6)$ proposes that the comic is a product of modernisation; that is, a new medium for the consumption of the burgeoning consumer of a new industrial age. It is a medium, therefore, that inherently expresses the rapid social changes brought about by industrialisation in the first half of the twentieth century. Scott McCloud $(1993,75)$ argues that the comic book genre predominately constructs stories through sequential depictions of actions. The panels employed to do this produce a particularly dynamic effect. The same dynamism is a constant feature in Patoruzú. The characters are constantly depicted, from one panel to another, moving rapidly through the city in pursuit of criminals or, in some cases, travelling from the city to the countryside in a single bound. The pace and movement of the storylines are also reflected in single panels whose 'líneas de movimiento y líneas expresivas destacan los efectos dinámicos' (Fiorani 2015, 295). In short, the formal techniques employed in the comic produce, above all, the effect of a constant, vibrant movement. As we have seen, one of the most important changes in Argentine society during the 30 s and 50 s was the mobility of people which, in part, took the form of mass internal migration and rapid demographic shifts. The very genre to which Patoruzú belongs articulates this new vibrant rapid-paced world within the dynamism of its sequential art.

Merino $(2003,6)$ also observes that social transformation is a central theme in the comics of Latin America from the same period. They are representational responses, often humorous, to the problems and concerns that communities and individuals confronted during the transition towards modernity. Comic strips, such as the Ranilla (1922) in Mexico, El Condorito (1945) in Chile, and El Supercholo (1957) in Peru, among others, all humorously delineate the experience of modernization and immigration to urban centres. Patoruzú cleary belongs to this group of Latin American comic books. The protagonist, after all, is the gaucho, the Indian, the campesiño (rural individual) who comes to live in the city and must adapt to urban life.

Quite often, this experience is delineated as something that threatens the loss of the moral values associated with his rural background. Patoruzú, as the comic's hero, is impervious to the great majority of the city's temptations and even when he does fall for them, usually because of a girl, he is unable to change despite his own 
desire to do so. For example, in the storyline of the January editions of 1940, Clorinda, a girl who Patoruzú has saved, falls in love with the heroic indian, but then realises his nose, a characteristic of his indigeneity, is too big and persuades him to go under the surgeon's knife. Patoruzú changes his mind at the last moment, but even when the surgeon attempts to enforce plastic surgery upon him, the knives do not even pierce his skin. Patoruzú's innate resistance to the corrupting and often garish and shallow aspects of city life can be read in the different ways already outlined previously: i.e. the nostalgic images of the 'authentic' gaucho/criollo as expressed within the national and political conflicts of the time. However, from another perspective, it can also be seen as a reflection of the more concrete and immediate nostalgia experienced presumably by the rural migrants in the process of becoming urbanised; in other words, as a form of wish fulfilment in which their traditions and links to the past will not disappear.

In other storylines the threat of loss through transition and adaptation is much greater. One of the most important and consistent tropes is the corruption of Apu, Patoruzú's brother. His youth, innate innocence, and comic capacity for consumption mean that he is far more susceptible to the temptations that Isidoro lays before him: money, drinking, and gambling. Interestingly, in one episode, Patoruzú deems that Apu has become so corrupted by the city and Isidoro's influence that he has lost his authentic Tehuelche identity. In $\mathrm{n} .331$ he decides to sends him back to Patagonia in order to be re-taught the tribe's 'destreza india' (indigenous skills) (17 January 1944, 8-9).

This important theme of identity loss is also expressed in other more subtle ways throughout the different stories of the comic book. An important and repeated expression reveals itself via the age-old comic repertoire of mistaken identity. In many of the episodes, Patoruzú and Apu must disguise themselves as typical city folk in order to foil the villains of the piece. In the storyline of the 1944 OctoberDecember editions, for example, Apu is persuaded to take the place of and dress up as Toto Platelli, a European prince who has disappeared, in order to keep his disappearance a secret from his ill mother. Meanwhile, Patoruzú dresses up as a city dweller in order to find Apu, who, in turn, has been kidnapped by a gang of criminals, who think he is Toto Platelli. The story is a clear pastiche of Mark Twain's The Prince and the Pauper (1881). However, more importantly, the episode discussed here, and there are many other similar ones, involve a confusion of identities, in which Apu and Patoruzú are required to don western-style clothes and, to a certain extent, adopt or pretend to adopt an urban identity. In doing this, they often fail to recognise each other. Identity confusion is of course a well-worn comic motif; however the narratives also display strong parallels with the rural migrant's dislocating experiences as they adapted to the demands of urbanisation and industrial modernisation. Arguably such 
storylines would have struck a chord with this section of Argentine society but also possibly with the European migrants. As we have seen, Adamovsky (2015) observes that this sector of the population also embraced the criollo symbols and took part in the street fairs and other celebrations of the traditions. Their adoption of such an identity in order assimilate themselves into Argentine society is also symptomatic of a sense of dislocation.

The storylines and the themes of displacement along with the generic characteristics of the comic book discussed above reveal another, final parallel between the contradictions in Patoruzú and the Peronist regime's employment of rural imagery. The figure of Patoruzú, as we have seen, reflects the narratives and values that Perón's party conferred upon the images of criollo and gaucho traditions: the timeless essence of an 'authentic Argentine identity' in the face of an encroaching and diaphanous cosmopolitanism. Yet the very genre employed to articulate this discourse inherently inscribes within its formalistic devices the intense and dynamic transformations that the criollo communities were undergoing. The same discrepancy exists within the mediums of modern popular culture employed in Peronist propaganda. The Juan Pablo poster, mentioned earlier, is as much a product of the industrial age as Patoruzú. Moreover both expose, perhaps unconsciously, the hypocrisy of the political obsession with criollismo. The industrial development and modernisation necessary to create the new independent Argentina was in fact uprooting and radically changing the very identity that was lauded as a 'genuine' symbol of national identity. Indeed one could argue that the transference of traditions practiced by the people (Poblete 2016, 13) into mediums of modern commercial culture and contemporary political discourse is indicative of their demise. ${ }^{13}$

To conclude, these social transformations suggest an intrinsic relationship between the popularity of Patoruzú (and other popular depictions of criollo culture) and the popularity of Peronism. The effects of migration and industrialisation logically brought about feelings of anxiety and social and economic insecurity. As Eric Fromm (1942) and from another perspective Catarina Kimmwall (2004) suggest, such feelings often lead groups to look for security in religion or nationalism or ideologies, like social corporatism, as well as in charismatic leaders. As we have seen, symbols are vitally important in such contexts. The comic book must have functioned during this period, therefore, as a link in a chain of symbols, which circulated within Peronist and other examples of nacionalismo popular, onto which such emotions were constantly transferred. Connected to this function is the other more specific emotive issue which the comic book broaches. All examples of criollo literature, art and political discourse can be seen as an expression of nostalgia. This potent emotion must have been felt even more acutely by the very groups that were losing this identity, with which the Peronist party, whether by luck or design, managed to form a 
This is an Accepted Manuscript of an article published by Taylor \& Francis in Journal of Latin

American cultural studies on 11 Dec 2017, available online:

http://www.tandfonline.com/10.1080/13569325.2017.1402753 17

connection. Yet, as we have seen, the criollo imagery employed to articulate (and in some cases manipulate) this nostalgia for political ends was a site of contestation and, therefore, open to multiple interpretations. The comic book Patoruzú is a footprint of these complex social, cultural and political conflicts that defined Argentina between the 1930 s and 50 s.

7308 words

\section{Notes}

1. Also see Quiroga Micheo $(1994,37)$ for the initial success of the comic, and Saccomanno and Trillo (1980) for its rivalry with the comics mentioned. The last edition, according to Fernando Ariel García (2014) was released in 1977.

2. Laura Vásquez $(2010,31)$ also identifies this type of 'innocent' nationalism in the comic.

3. The gaucho is known in Argentina as a cowboy, whose identity is made up of indigenous and Spanish colonial traditions.

4. According to study published by the Departamento de Estudios Demográficos the importance of internal migrations has been overshadowed by the strategic importance of international migrants. Based on the data of the 1947 censor, the report reveals that 962.928 of the total population of the province of Buenos Aires, 4.272.337, were internal migrants. That makes $22.5 \%$ of the total population of that area. It exceeds the number of foreign migrants, 775.414 , by almost 200.000 . According to the same study $24.6 \%$ of the total population of Argentina were internal migrants, who had also migrated to other urban centres such as Santa $\mathrm{Fe}$, which makes a total of 3.814.518. The report 'Migraciones internas en la provincia de Buenos Aires' can be found at the following web address: http://www.ec.gba.gov.ar/estadistica/pdf/migraciones.pdf. Accessed June 2016.

5. According to Milanesio $(2010,53)$, ' $78 \%$ of urban workers living in Buenos Aires were migrants from other provinces'.

6. Peter Beardsall (1973) and Jorge Borges (1987) are two principal representatives of these arguments about Argentine literature. Jorge B. Rivera (1981, iv) sees the criollista comics as a recuperation of the rural past of Argentina.

7. Interestingly Trillo and Saccomanno (1980) identify a similar political theme in Patoruzito, a spin-off comic about the early life of the hero.

8. It is also interesting to note here that in early versions of the magazine Steimburg $(1982,171)$ and Matamoro $(1980,157)$ note a contradictory political theme in the editorial sections of the comic, which supports neoliberal and oligarchic political positions. However, Steimburg (172) notes that the anti-Peronist comments in these editorials begin to disappear in the 1940s.

9. Quinterno's own words about the creation and characteristics of Patoruzú certainly echo Viñas' and Polar's analysis of the romanticised and neo-colonial imagery of indigenous and rural culture in which middle-class politics and desires can be identified. After having studied the psychology of the 'indios' (indians), he states that he was impressed most by their 'bonachón e ingenuo' (good natured and naive) characteristics. The interview with Quinterno was published in 1931 in the magazine Aconcagua (see webpage Dante Quinterno, http://www.todohistorietas.com.ar/quinterno2.htm, accessed 15 July 2014). On the other end of the scale, the stereotype of the 'pre-modern' Argentine in its negative form of barbarism was also an important ingredient in the discourse of the anti-Peronists during the 40s and 50s (Milanesio 2010, 59), which shows that different factions of Argentine society and class employed stereotypes of the rural 'other' in order to express their political aims and social anxieties.

10. The position in which comics found themselves was obviously framed by the modernists' rejection of massculture as anti-art, which a priori excluded them from the national canon. Prieto's review $(1988,40-1)$ of the critical attitudes towards the many other examples of popular criollismo of the period highlights this elitist rejection of mass culture in the period. Jean Franco (1999) discusses, more specifically, the problematic relationship between comics and the national tradition in Argentina.

11. See endnotes 5 and 6 for the figures of internal migration.

12. While westernised and political ideas of anarchism did reach some areas of the interior, according to Juan Suriano (2001, iv) its impact was almost irrelevant in most rural societies.

13. From a different perspective Ana Merino $(2015,169)$ argues that the early versions of the comic strip published in the newspaper Crítica, before the launch of the by-weekly comic book studied in this article, are 
symptomatic of the assimilation of stereotypical representations of indigenous peoples into Argentine national discourse, which totally ignore the history of their near extermination and continued marginalisation and suffering. It is difficult not to agree with Merino here, however, we can also say that the rural/criollo migrants were undergoing a similar process in the early half of the twentieth century. Due to migration and modernization their social and cultural traditions were being eroded, while representations of their identity were being used as discourses of national identity and to promote different political aims. Moreover, as we have seen, the metropolitan employment of these symbols in modern mass-media genres constantly conflated indigenous and criollo identities, which was also part of a very real erasure of the different sociocultural identities of rural Argentina.

\section{References}

Adamovsky, Ezequiel. 2015. "El criollismo en las luchas por la definición del origen y el color del ethos argentino: 1944-55." Estudios Interdisciplinarios de América Latina y el Caribe 26 (1): 31-63.

Armstrong, John. 1982. Nations before Nationalism. Chapel Hill: The University of North Carolina Press.

Beardsall, Peter. 1973. "Introduction." In Don Segunda Sombra, 1-22. Oxford: Pegamon Press.

Borges, Jorge. 1987. "El escritor argentino y la tradición." In Discusión, Obras Completas, 267-74. Buenos Aires: Emecé.

Chamosa, Oscar. 2010. The Argentina Folklore Movement: Sugar Elites, Criollo Workers and its Politics of Cultural Nationalism. Tuscon: University of Arizona Press.

Chamosa, Oscar. 2010a. "Criollo and Peronist: The Argentine Folklore Movement in the First Peronism, 1943-1955." In The New Cultural History of Peromism: Power and Identity in Mid-Twentieth-Century Argentina, edited by Oscar Chamosa and Matthew Karush, 113-142. London: Duke University Press.

Cohen, Antonio. 1995. The Symbolic Construction of the Community. London: Routledge.

Cornejo Polar, Anthony. 1977. Literatura y sociedad en el Perú: La novela indigenista. Lima: Editorial Lasontay.

Cortázar, Augusto Raúl. 1939. El folklore y el concepto de nacionalidad. Buenos Aires: UBA. 
Cullen, Rafeal. 2009. Clase obrera lucha armada, Peronismos: Génesis, desarrollo y crisis del Peronismo original: Buenos Aires: De la Campana.

Dante

Quinterno.

Accessed

15

July

2014.

http://www.todohistorietas.com.ar/quinterno2.htm.

Departamento de Estudios Demográficos. "Migraciones internas en la provincia de Buenos Aires." Ministerio de Economía: Buenos Aires Provincia. Accessed June 2016. http://www.ec.gba.gov.ar/estadistica/pdf/migraciones.pdf.

Fernández Latour de Botas, Olga, and Marta Silivia Ruiz de Barrantes. 1990. La búsqueda de la identidad nacional en la década del 30. Buenos Aires: Cometa.

Fernando Ariel García, Hernan Ostuni. 2014. "Vera historia de Indio Patoruzú." Tebeosfera,

http://www.tebeosfera.com/documentos/documentos/vera historia del indio patoruzu.html

Fiorani, Flavio. 2015. “¡Por fin llegaste, Patoruzú! Un exitoso icono de la historieta argentina." Confluenze, 7 (1): 281-302.

Franco, Jean. 1999. "Comic Stripping: Cortázar and the Age of Mechanical Reproduction." In Critical Passions: Selected Essays, edited by Mary Louise Pratt and Kathleen Newman, 405-25. Durham: Duke University Press.

Fromm, Erich. 1942. The Fear of Freedom. London: Butler \& Tanner.

García Canclini, Néstor. 1990. Culturas híbridas: estrategias para entrar y salir de la modernidad. México D.F.: Editorial Grijalbo.

Gelbart, Matthew. 2007. The Invention of "Folk Music" and "Art Music": Emerging Categories from Ossian to Wagner. Cambridge: CUP.

Gobello, José. 2004. Costumbrismo Lunfardo. Buenos Aires: Editorial Duerhen.

Gordon, Ian. 1998. Comic Strips and Consumer Culture: 1890-1945. London: Smithsonian Institution Press.

Hall, Stuart. 1980. "Encoding/Decoding." In Culture, Media, Language, edited by Stuart Hall, Dorothy Hobson, Andrew Lowe, and Paul Willis, 34-50. London: Hutchinson.

Hobsbawn, Eric, and Terence Ranger. 1992. The Invention of Tradition. Cambridge: CUP. 
Karush, Matthew. 2010. "Populism, Melodrama, and the Market: The Mass Cultural Origins of Peronism." In The New Cultural History of Peromism: Power and Identity in Mid-Twentieth-Century Argentina, edited by Oscar Chamosa and Matthew Karush, 21-51. London: Duke University Press.

Kimwall, Catarina. 2004. "Globalisation and Religious Nationalism: Self Identity and Search for Ontological Identity." Political Psychology 25 (5): 741-767.

Larraín, Jorge. 1997. "Modernidad e identidad en América Latina." Universum: Revista de Humanidades y Ciencias Sociales 12. Accessed June 32014 http://universum.utalca.cl/contenido/index-97/larrain.html

Lipzic, David. 1982. "Argentina: Comics hasta los años 40. Patoruzú un superhéroe de las Pampas." En Historia de los comics, tomo II, edited by Javier Coma, 13-24. Barcelona: Toutain Editor.

Lorenzo Álvarez, Elena de. 2005. La construcción de una identidad: el mundo indígena en la literatura independentista. Alicante: Biblioteca Virtual Miguel de Cervantes.

Malatesta, Parisina. 1997. "A Southern Cone Superman." Américas, March 1: 46

Matamoro, Blas. 1980. Saber literatura: por una crítica epistemología. Madrid: Ediciones de La Torre.

McAllister, Matthew, Edward H. Sewell and Ian Gordon. 2001. "Introducing Comics and Ideology." In Comics and Ideology, 3-13. NY: Peter Lang.

McCloud, Scott. 1993. Understanding Comics: The Invisible Art. New York: Harper Collins.

Merino, Ana. 2015. "Fake Nostalgia for the Indian: The Argentinean Fiction of National Identity in the Comic Patoruzú." In No Laughing Matter: Visual Humour in Ideas of Race, Nationality and Ethnicity, edited by David Bindman and Adrian W. B. Randolph, 149-75. New England: Dartmouth College Press

Merino, Ana. 2003. El comic hispánico: Madrid: Cátedra.

Milanesio, Natalie. 2010. "Peronists and Cabecitas: Stereotypes and Anxieties at the Peak of Social Change." In The New Cultural History of Peromism: Power and Identity in Mid-Twentieth-Century Argentina, edited by Oscar Chamosa and Matthew Karush, 53-84. London: Duke University Press.

Penna, Julio and Norberto Ras. 2003. Una identidad en crisis: pasado, presente y futuro de una esperanza. Buenos Aires: Editorial Galerna. 
Poblete, Juan. 2016. "Cinema and Humour in Latin American: An Introduction." In Humor in Latin American Cinema, edited by Juan Poblete and Juana Suárez, 1-28. New York: Palgrave Macmillan.

Prieto, Adolfo. 1988. El discurso criollista en la formación de la Argentina moderna. Buenos Aires: Editorial Sudamericana.

Quinterno, Dante. 1936-50. Patoruzú. Buenos Aires: Editorial Dante Quinterno.

Quiroga Micheo, Ernesto. 1994. "Patoruzú, la historieta que ya es historia." Todo es historia, junio 323: 34-42.

Rivera, Jorge B. 1981. "Prólogo." En Fuerte Argentino, by Julio A. Portas and Walter Ciocca, i-v. Buenos Aires: Centro Editor de América Latina.

Saccamanno, Guillermo and Carlos Trillo. 1980. Historia de la historieta de argentina. Buenos Aires: Ediciones Record.

Schelling Vivian. 2000. Through the Kaleidoscope: the Experience of Modernity in Latin America. London: Verso.

Smith, Anthony. 2003. Chosen People: Sacred Sources of Identity. Oxford: OUP.

Stiemburg, Oscar. 1982 [1970]. "Historieta e ideología en la Argentina: 1936-1937 en la vida de Patoruzú." En La historieta en el mundo moderno, edited by Oscar Masotta, 159-173. Barcelona: Paidós.

Suriano, Juan. 2001. Cultura y política libertaria en Buenos Aires, 1890-1910. Buenos Aires: Manantial.

Tur Donatti, Carlos. 2008. "La Argentina blanca y europeizada, agonía de un mito oligárquico." Antropología: Boletín Oficial del Instituto de Antropología e Historia 81: 114-118.

Vásquez, Laura. 2010. El oficio de las viñetas: la industria de la historieta argentina. Buenos Aires: Paidós.

Viñas, David. 1982. Indios, ejércitos y frontera. México: Siglo XXI Editores. 
This is an Accepted Manuscript of an article published by Taylor \& Francis in Journal of Latin

American cultural studies on 11 Dec 2017, available online: http://www.tandfonline.com/10.1080/13569325.2017.1402753 22 